\title{
Development and Evaluation of Nanoscale Sorbents for Mercury Capture from Warm Fuel Gas
}

\author{
Preliminary Sorbent Evaluation (Task 3) \\ Topical Report - 2
}

Reporting Period

December 01, 2004 - September 30, 2005

By

Raja A. Jadhav, Ph.D.

Howard Meyer

October 2005

Work Performed under Contract No. DE-FC26-04NT42312

September 27, 2004 - March 26, 2006

For

U.S. Department of Energy, National Energy Technology Laboratory (NETL)

Ronald Breault, Project Manager

3610 Collins Ferry Road, P.O. Box 880

Morgantown, WV 26507-0880

Submitted by

Gas Technology Institute (GTI)

1700 S. Mount Prospect Road

Des Plaines, IL 60018

GTI Project Number 20162

Subcontractor

NanoScale Materials, Inc.

1310 Research Park Dr., Manhattan, KS 66502

Technical Point of Contact

Raja A. Jadhav, Ph.D.

Engineer, GTI

Phone: (847) 768-0807, Fax: (847) 768-0600

E-mail: raja.jadhav@gastechnology.org 


\section{DISCLAIMER}

This report was prepared as an account of work sponsored by an agency of the United States Government. Neither the United States Government nor any agency thereof, nor any of their employees, makes any warranty, expressed or implied, or assumes any legal liability or responsibility for the accuracy, completeness, or usefulness of any information, apparatus, product, or process disclosed, or represents that its use would not infringe privately owned rights. Reference herein to any specific commercial product, process, or service by trade name, trademark, manufacturer, or otherwise does not necessarily constitute or imply its endorsement, recommendation, or favoring by the United States Government or any agency thereof. The views and opinions of authors expressed herein do not necessarily state or reflect those of the United States Government or any agency thereof. 


\begin{abstract}
Several nanocrystalline sorbents were evaluated for their mercury-sorption capacity in GTI's mercury-sorbent testing facility. These preliminary tests were carried out in mercury-laden $\mathrm{N}_{2}$ stream at 423 and $533 \mathrm{~K}$. Desorption tests on the post-sorbed sorbents were carried out to understand the mechanism of interaction between mercury and the sorbent. Of the eight nanocrystalline sorbents evaluated, NanoActive $\mathrm{Cr}_{2} \mathrm{O}_{3}$ was the most effective sorbent at both 423 and $533 \mathrm{~K}$. NanoActive $\mathrm{MnO}_{2}$ and $\mathrm{CuO}$ sorbents also showed promise for capture of mercury from N2 stream. Desorption tests indicated that the capture of mercury took place by a combination of physical and chemical adsorption. It is speculated that the NanoActive metal oxides oxidized mercury to HgO form that was immobilized on the sorbent surface. Presulfidation of NanoActive $\mathrm{CuO}$ increased its Hg-sorption capacity at $423 \mathrm{~K}$; however, presulfided NanoActive $\mathrm{MnO}_{2}$ sorbent became ineffective for $\mathrm{Hg}$ capture at both 423 and $533 \mathrm{~K}$.
\end{abstract}




\section{TABLE OF CONTENTS}

ABSTRACT

LIST OF FIGURES $\quad$ iv

EXECUTIVE SUMMARY $\quad$ v

1. Experimental Methods $\quad 1$

2. Results and Discussion 2

3. Conclusion $\quad 6$ 


\section{LIST OF FIGURES}

Figure 1 Schematic of GTI’s experimental setup for mercury sorbent testing 2

Figure 2 Mercury breakthrough plot for NanoActive-D $\mathrm{MnO}_{2} /$ alumina sorbent at $423 \mathrm{~K} 3$

Figure 3 Adsorption/desorption studies on NanoActive $\mathrm{MnO}_{2}$ sorbent 4

Figure 4 Adsorption/desorption studies on NanoActive $\mathrm{Cr}_{2} \mathrm{O}_{3}$ sorbent 5

Figure 5 Mercury breakthrough plot for NanoActive $\mathrm{CuO}$ at $423 \mathrm{~K}$ 


\section{EXECUTIVE SUMMARY}

Gas Technology Institute (GTI), in collaboration with Nanoscale Materials, Inc. (NanoScale), is developing and evaluating several nanocrystalline sorbents for capture of mercury from coalgasifier (such as IGCC) warm fuel gas. The focus of this study is on the understanding of fundamental mechanism of interaction between mercury and nanocrystalline sorbents over a range of fuel gas conditions. Detailed chemical and structural analysis of the sorbents will be carried out using an array of techniques, such as XPS, SEM, XRD, $\mathrm{N}_{2}$-adsorption, to understand the mechanism of interaction between the sorbent and mercury.

The proposed nanoscale oxides have significantly higher reactivities as compared to their bulk counterparts, which is a result of high surface area, pore volume, and nanocrystalline structure. These metal oxides/sulfides will be evaluated for their mercury-sorption potential in an experimental setup equipped with state-of-the-art analyzers. Initial screening tests will be carried out in $\mathrm{N}_{2}$ atmosphere, and two selected sorbents will be evaluated in simulated fuel gas containing $\mathrm{H}_{2}, \mathrm{H}_{2} \mathrm{~S}$, Hg and other gases. The focus will be on development of sorbents suitable for higher temperature (420-640 K) applications.

Activities in Task 3 were focused on preliminary evaluation of eight nanocrystalline metal oxide sorbents for mercury capture. The sorbents were synthesized by NanoScale and sent to GTI for evaluation in GTI's mercury-sorbent testing facility. The preliminary sorbent testing was carried out in Hg-laden $\mathrm{N}_{2}$ stream at 423 and $533 \mathrm{~K}$ to screen effective sorbents for detailed evaluation in simulated fuel gas. The concentration of mercury was maintained about $135 \mu \mathrm{g} / \mathrm{m}^{3}$ in $3 \mathrm{lpm}$ of $\mathrm{N}_{2}$ stream. The metal oxide sorbents were also presulfided to understand the effect of sulfur in capture of mercury. The screening tests concluded that NanoActive $\mathrm{Cr}_{2} \mathrm{O}_{3}$ was the most effective sorbent for $\mathrm{Hg}$ removal from $\mathrm{N}_{2}$ stream at both 423 and $533 \mathrm{~K}$. During a 6-h exposure to $\mathrm{Hg}$ at $423 \mathrm{~K}$, NanoActive $\mathrm{Cr}_{2} \mathrm{O}_{3}$ captured nearly $100 \%$ of the $\mathrm{Hg}$ with a Hg-loading of 720 $\mu \mathrm{g} / \mathrm{g}$ sorbent. At $533 \mathrm{~K}$, the sorbent captured $73 \%$ of exposed mercury giving a $\mathrm{Hg}$ loading of $530 \mu \mathrm{g} / \mathrm{g}$ sorbent. NanoActive $\mathrm{MnO}_{2}$ and $\mathrm{CuO}$ also showed promise for $\mathrm{Hg}$ capture. Desorption tests on post-sorption sorbents indicated a combination of physical and chemical sorption mechanisms. Detailed mechanistic studies on the metal oxides suggested catalytic oxidation and subsequent capture of $\mathrm{Hg}$ by the sorbent. Presulfidation of NanoActive $\mathrm{CuO}$ increased its Hgsorption capacity at $423 \mathrm{~K}$; however, presulfided NanoActive $\mathrm{MnO}_{2}$ sorbent became ineffective for $\mathrm{Hg}$ capture at both 423 and $533 \mathrm{~K}$. 


\section{Experimental Methods}

Nanocrystalline Sorbents

Seven different nanocrystalline metal oxides (viz., NanoActive ${ }^{\circledR} \mathrm{TiO}_{2}, \mathrm{CeO}_{2}, \mathrm{ZnO}, \mathrm{CuO}$ and NanoActive ${ }^{\circledR}$ - $\mathrm{D} \mathrm{MoO}_{3}, \mathrm{Cr}_{2} \mathrm{O}_{3}$, and $\mathrm{MnO}_{2}$ ) were synthesized by NanoScale using their proprietary techniques. In addition, a NanoActive- $\mathrm{DnO}_{2}$ /alumina was also synthesized, which is a supported sorbent with about $30 \mathrm{wt} . \% \mathrm{MnO}_{2}$ on a high surface area alumina support. The nanomaterials were pelletized by pressure-compaction method and ground to the desired size range $(180-250 \mu \mathrm{m})$.

\section{Experimental Setup}

The sorbents are evaluated in a lab-scale, fixed bed reactor with the outlet mercury concentration monitored by a semi-continuous mercury analyzer. As shown in Figure 1, the mercury sorbent testing unit essentially consists of a quartz reactor shell and a quartz reactor insert that are externally heated by a three-zone electric furnace. The setup is complete with equipment for feeding and measuring the flow rate of the gases, measuring and controlling the bed temperature, monitoring the reactor pressure and the pressure drop across the bed, off-gas sampling and analysis, and an automated data acquisition system. The reactor system is configured for upward gas flow, and the three-zone furnace is positioned with respect to the sorbent bed to accomplish feed gas preheating. Certified elemental mercury $\left(\mathrm{Hg}^{0}\right)$ permeation tube from VICI Metronics is used to generate the $\mathrm{Hg}^{0}$ vapor. The permeation tube is housed in a VICI Metronics U-tube, heated in a constant temperature water bath. The reactor insert has a $2.3 \mathrm{~cm}$ O.D. and a $1.8 \mathrm{~cm}$ I.D. sorbent bed cage of a $1 \mathrm{~cm}$ height. The top of the cage is a fixed porous frit, while the bottom consists of a similar, but removable porous frit to allow for placement of the sorbent. The height of the sorbent bed is maintained around $0.5 \mathrm{~cm}$, with the bed sandwiched between quartz wool packing. A "semi-continuous" gas-phase mercury analyzer (PSA Sir Galahad II) is used to monitor the concentration and speciation of mercury in the gas stream.

\section{Experimental Procedure}

Approximately $0.2 \mathrm{~g}$ of the sorbent (size range $180-250 \mu \mathrm{m}$ ) is mixed with $1.8 \mathrm{~g}$ of inert alumina (size range 250-425 $\mu \mathrm{m}$ ) to prevent channeling of mercury within the sorbent bed. The sorbent is loaded in the quartz reactor insert and the sorbent bed is supported by quartz wool and porous frit on both sides. Next, the reactor is inserted in the shell and preheated to the desired temperature in flowing $2.6 \mathrm{lpm}$ of $\mathrm{N}_{2}$ stream. A mercury permeation tube is used as a source of mercury with $0.4 \mathrm{lpm} \mathrm{N}_{2}$ used as a mercury carrier stream. When the temperature, flow rate, and bypass mercury concentration values are stabilized, the mercury is sent to the sorbent, and the outlet concentration (including mercury speciation) is monitored and recorded by the PSA analyzer. The mercury loading on the sorbent is calculated based on the area above the breakthrough curve. For selected experiments, this result is confirmed using a DMA-80 Direct Mercury Analyzer from Milestone, Inc., which measures total mercury loaded on the sorbent.

\section{Presulfidation of Sorbents}

To evaluate $\mathrm{Hg}$ capture by nanocrystalline metal sulfides, $\mathrm{NanoActive} \mathrm{CuO}$ and $\mathrm{MnO}_{2}$ sorbents were presulfided in the presence of 0.5 slpm of $10 \% \mathrm{H}_{2} \mathrm{~S} / \mathrm{N}_{2}$ stream for $3 \mathrm{~h}$. The sulfidation of NanoActive $\mathrm{CuO}$ and $\mathrm{MnO}_{2}$ was carried out at $423 \mathrm{~K}$ and $573 \mathrm{~K}$, respectively. 


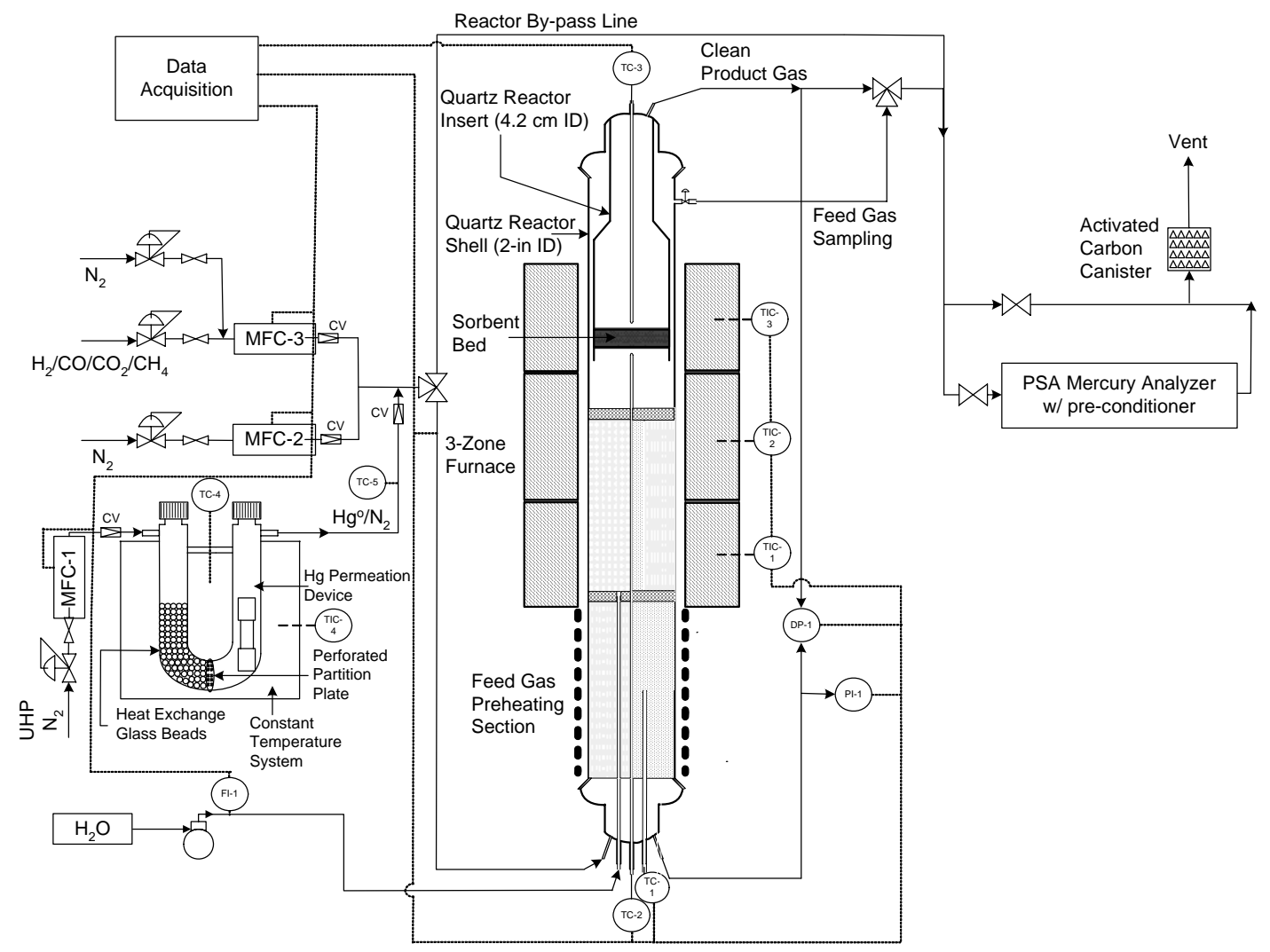

Figure 1: Schematic of GTI’s experimental setup for mercury sorbent testing

\section{Results and Discussion}

\section{Evaluation of NanoActive Sorbents for Mercury Capture}

Mercury sorption capacities of the eight NanoActive metal oxides were determined by following the procedure given earlier. The sorption studies were carried out at two different temperatures of 423 and $533 \mathrm{~K}$ with 3 slpm of Hg-laden $\mathrm{N}_{2}$ stream. The inlet mercury concentration varied over the range of $125-140 \mu \mathrm{g} / \mathrm{m}^{3}$ for these experiments, believed to be due to the day-to-day variation of the analyzer calibration.

NanoActive $\mathrm{TiO}_{2}, \mathrm{CeO}_{2}, \mathrm{ZnO}$ and $\mathrm{MoO}_{3}$ sorbents were ineffective in capturing mercury, and their Hg-sorption capacities were negligible at both the temperatures. Table 1 gives a summary of the results for the NanoActive $\mathrm{CuO}, \mathrm{MnO}_{2}, \mathrm{MnO}_{2}$ /alumina, and $\mathrm{Cr}_{2} \mathrm{O}_{3}$ sorbents. It should be noted that the Hg-sorption capacity given in the table represents the sorbent capacity for the duration for which the sorbent was exposed to mercury, and not the saturation sorption capacity. In this table, the total mercury captured as a percentage is calculated by dividing the total mercury captured by the sorbent by the total mercury exposed to the sorbent. 
Table 1: Comparison of Hg-sorption capacities of NanoActive ${ }^{\circledR}$ sorbents

\begin{tabular}{|c|c|c|c|c|c|c|c|c|}
\hline & \multicolumn{4}{|c|}{$423 \mathrm{~K}$} & \multicolumn{4}{|c|}{$533 \mathrm{~K}$} \\
\hline & $\mathrm{CuO}$ & $\mathrm{MnO}_{2}$ & $\begin{array}{r}\mathrm{MnO}_{2} / \\
\text { alumina }\end{array}$ & $\mathrm{Cr}_{2} \mathrm{O}_{3}$ & $\mathrm{CuO}$ & $\mathrm{MnO}_{2}$ & $\begin{array}{c}\mathrm{MnO}_{2} / \\
\text { alumina }\end{array}$ & $\mathrm{Cr}_{2} \mathrm{O}_{3}$ \\
\hline $\begin{array}{l}\text { Inlet Hg conc., } \\
\mu \mathrm{g} / \mathrm{m}^{3}\end{array}$ & 130 & 125 & 138 & 130 & 140 & 132 & 135 & 133 \\
\hline $\begin{array}{l}\text { Final outlet Hg } \\
\text { conc., } \mu \mathrm{g} / \mathrm{m}^{3}\end{array}$ & 97 & 45 & 10 & 4 & 140 & 106 & 75 & 56 \\
\hline Sorption time, h & 6 & 6 & 4 & 6 & 2.5 & 5 & 6 & 6 \\
\hline $\begin{array}{l}\text { Hg-sorption } \\
\text { capacity, } \mu \mathrm{g} / \mathrm{g}\end{array}$ & 250 & 490 & 480 & 720 & 74 & 230 & 500 & 530 \\
\hline $\begin{array}{l}\begin{array}{l}\text { Total Hg captured, } \\
\%\end{array} \\
\end{array}$ & 36 & 73 & 97 & $\sim 100$ & 21 & 32 & 70 & 73 \\
\hline
\end{tabular}

Of the eight nanocrystalline sorbents evaluated so far in this work, NanoActive- $\mathrm{D} \mathrm{Cr}_{2} \mathrm{O}_{3}$ was the most effective at both the temperatures. Increasing the NanoActive $\mathrm{MnO}_{2}$ sorbent surface area by supporting it on a high surface area alumina increased the Hg-sorption capacity of the sorbent, which suggest that the sorption of $\mathrm{Hg}$ takes primarily at the surface. Although the Hg-capacities of NanoActive $\mathrm{Cr}_{2} \mathrm{O}_{3}$ and $\mathrm{MnO}_{2}$ /alumina are similar, the surface area of the latter is more than twice that of the former ( $240 \mathrm{vs} .103 \mathrm{~m}^{2} / \mathrm{g}$ ). Since Hg-sorption is a surface phenomenon, Hgsorption capacities should be compared based on the sorbent surface area. Therefore, it can be concluded that the Hg-sorption capacity of $\mathrm{Cr}_{2} \mathrm{O}_{3}$ is higher than that of $\mathrm{MnO}_{2}$.

Figure 2 shows a typical $\mathrm{Hg}$ breakthrough plot for NanoActive $\mathrm{MnO}_{2} /$ alumina sorbent at $423 \mathrm{~K}$.

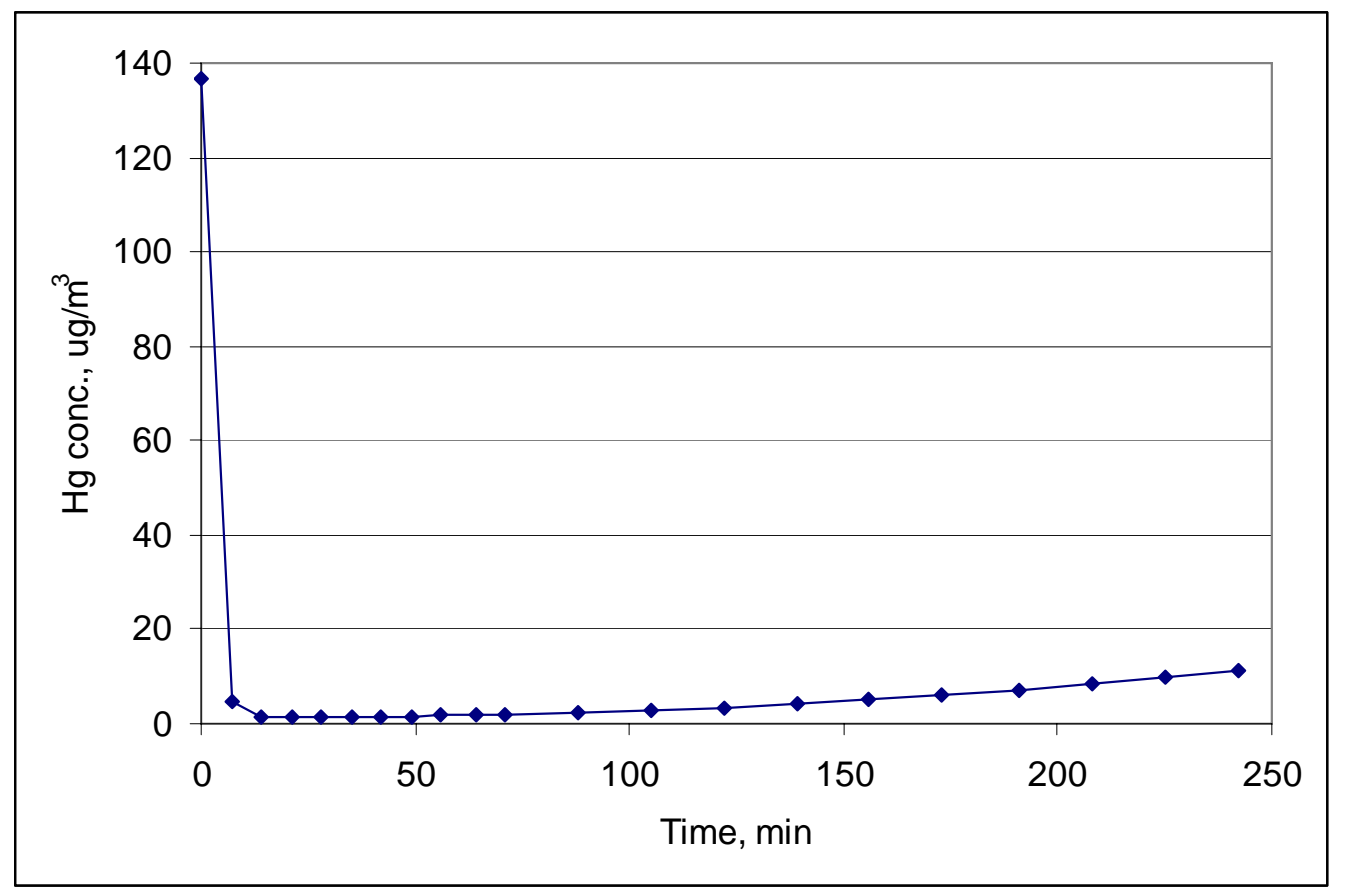

Figure 2: Mercury breakthrough plot for NanoActive-D $\mathrm{MnO}_{2} /$ alumina sorbent at $423 \mathrm{~K}$ 


\section{Mechanism of Mercury Capture by Sorbents}

Results in Table 1 indicate that mercury-sorption capacity of the sorbents decrease at higher temperature, suggesting that physical adsorption is the controlling mechanism of mercury capture. As outlined below, further studies were carried out to understand the mechanism of interaction between mercury and the sorbents.

NanoActive $\mathrm{MnO}_{2}$ Sorbent: To further confirm the physical adsorption mechanism for NanoActive ${ }^{\circledR} \mathrm{MnO}_{2}$ sorbent, an experiment was carried out in which the sorbent, after exposure to the mercury stream, was exposed to mercury-free $\mathrm{N}_{2}$ stream. Figure 3 shows the adsorption and desorption cycle for NanoActive ${ }^{\circledR} \mathrm{MnO}_{2}$ sorbent. In this experiment, approx. $0.1 \mathrm{gm}$ of the sorbent was mixed with 1.9 gm of inert alumina and exposed to $115 \mu \mathrm{g} / \mathrm{m}^{3}$ of $\mathrm{Hg} / \mathrm{N}_{2}$ stream at $423 \mathrm{~K}$. After $1 \mathrm{~h}$ of exposure, the mercury stream was diverted to the vent and only $\mathrm{N}_{2}$ was passed over the sorbent. At approx. $2.75 \mathrm{~h}$ into the desorption stage, temperature of the sorbent was increased to $468 \mathrm{~K}$. This temperature increase resulted in further release of adsorbed mercury from the sorbent. The amount of $\mathrm{Hg}$ released by sorbent in the $\mathrm{N}_{2}$ stream was recorded by the PSA mercury analyzer. Calculations indicate that about $16 \mu \mathrm{g}$ of $\mathrm{Hg}$ was captured by the sorbent during adsorption, whereas, only $3.6 \mu$ g of total Hg was released during desorption. Therefore, it is concluded that $\mathrm{Hg}$ is adsorbed on the sorbent surface by physical (weak van der Waal's forces) as well as strong chemical forces, and a much higher temperature is required for its complete release from the sorbent surface.

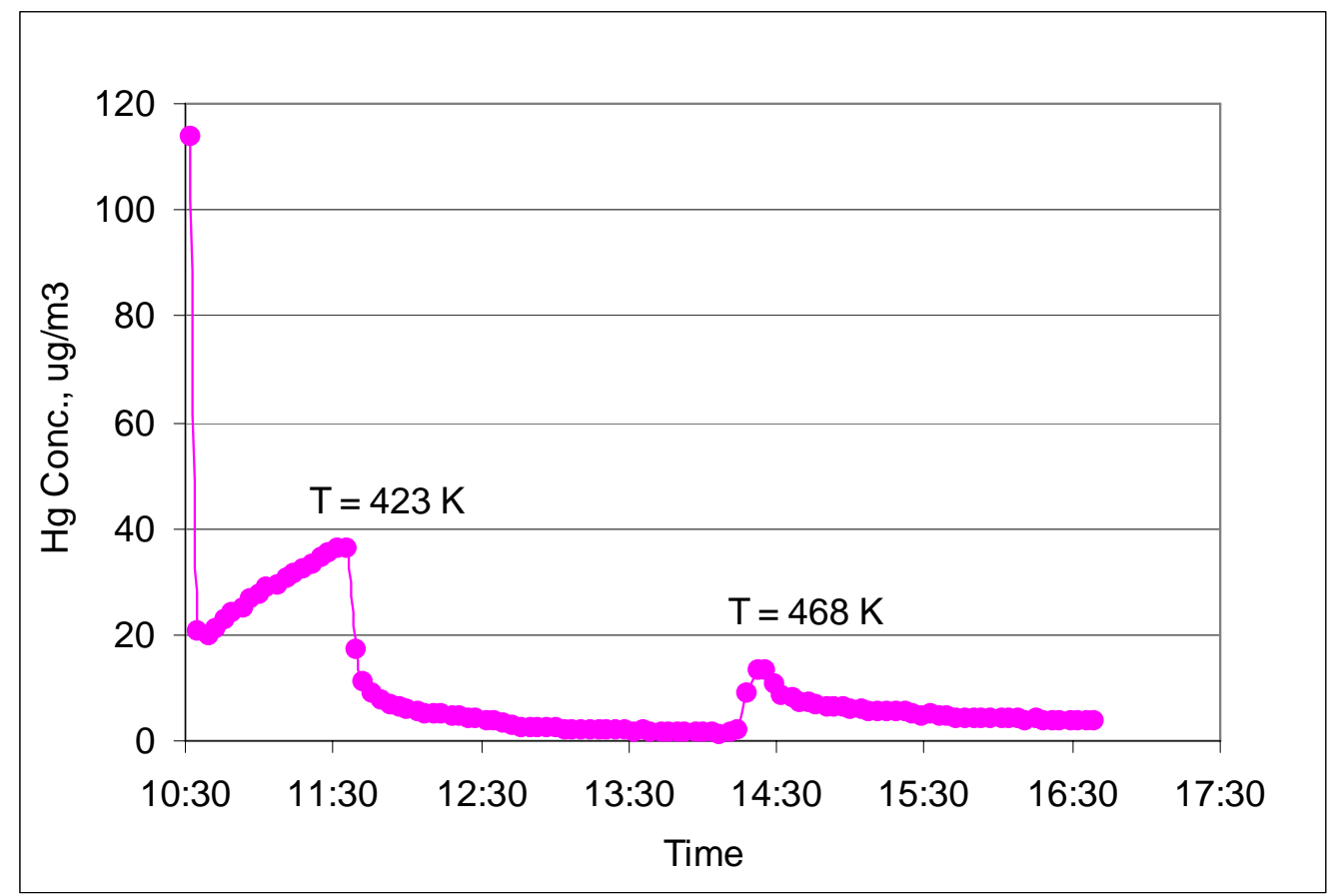

Figure 3: Adsorption/desorption studies on NanoActive $\mathrm{MnO}_{2}$ sorbent

NanoActive $\mathrm{Cr}_{2} \underline{\mathrm{O}}_{3}$ sorbent: Adsorption/desorption studies were also carried out for NanoActive $\mathrm{Cr}_{2} \mathrm{O}_{3}$ sorbent. As shown in Figure 4, after $\mathrm{Hg}$ adsorption for $1 \mathrm{~h}$ at $423 \mathrm{~K}$ in $\mathrm{N}_{2}$, the sorbent temperature was gradually increased to 443, 473, and $523 \mathrm{~K}$ in Hg-free $\mathrm{N}_{2}$ stream. The amount of mercury released increased with the desorption temperature. However, of the $22.6 \mu \mathrm{g}$ of $\mathrm{Hg}$ captured during the 1-h adsorption, only $2.7 \mu$ g of $\mathrm{Hg}$ was released during desorption, suggesting that the balance $\mathrm{Hg}$ is captured on the sorbent surface by stronger chemical forces. 


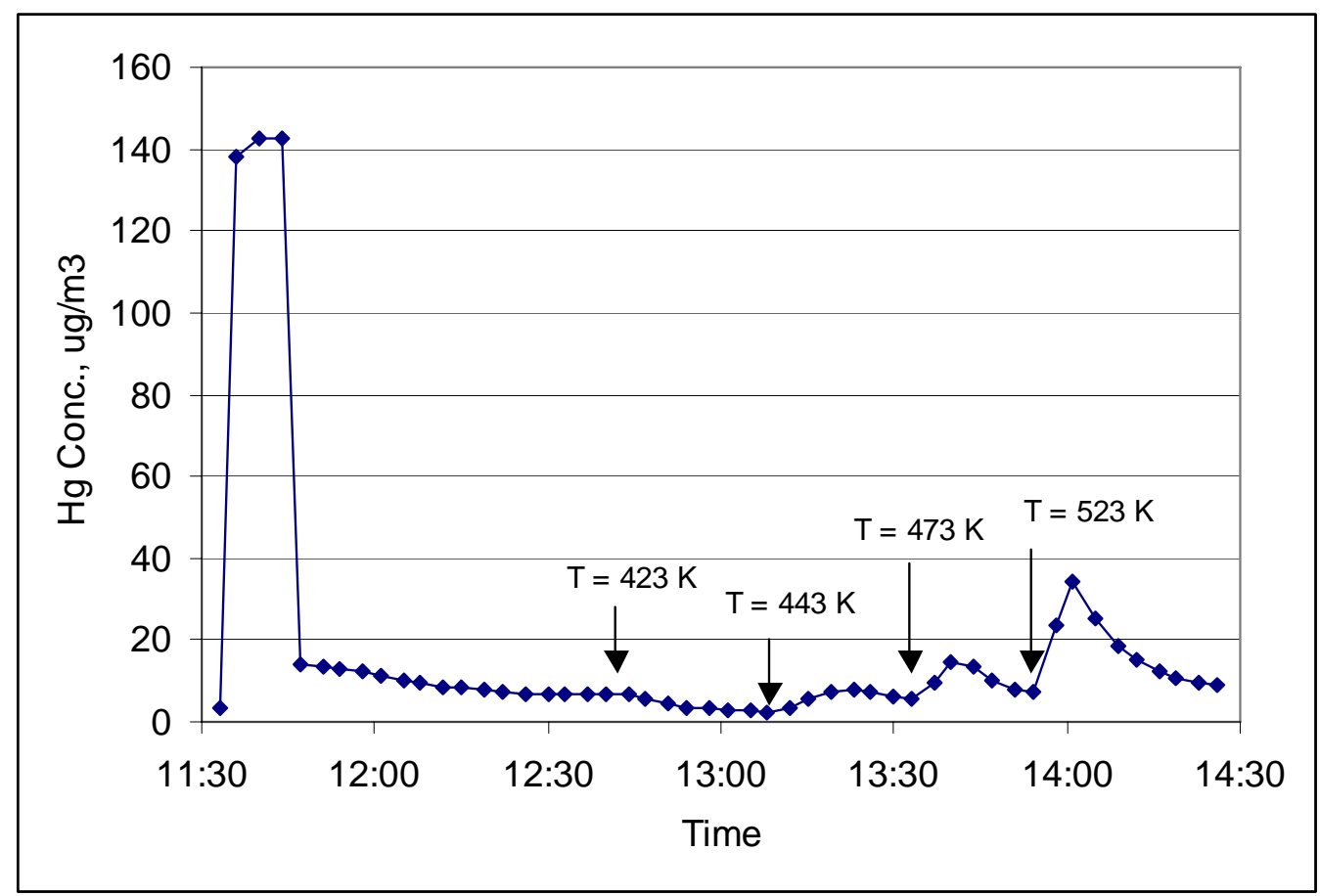

Figure 4: Adsorption/desorption studies on NanoActive $\mathrm{Cr}_{2} \mathrm{O}_{3}$ sorbent

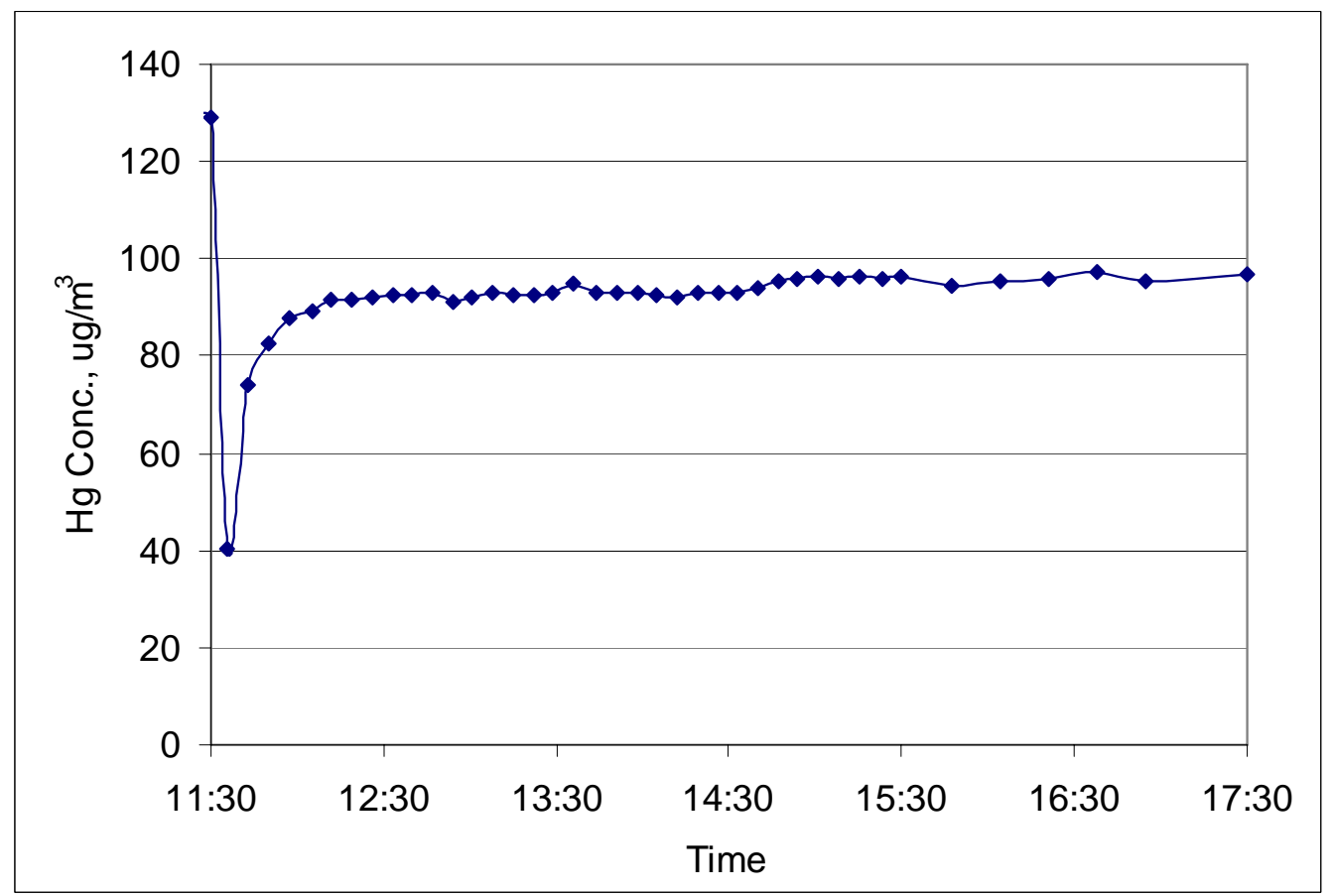

Figure 5: Mercury breakthrough plot for NanoActive $\mathrm{CuO}$ at $423 \mathrm{~K}$ 
An oxidation mechanism has been suggested by Granite et al. ${ }^{1}$ for capture of $\mathrm{Hg}$ by metal oxide catalysts such as $\mathrm{MnO}_{2}$ and $\mathrm{Cr}_{2} \mathrm{O}_{3}$. According to the proposed mechanism, in the first step of the capture process, gas phase $\mathrm{Hg}$ is physically adsorbed on the sorbent surface, which in the second step is oxidized to HgO by the lattice oxygen of the metal oxide $\left(\mathrm{M}_{\mathrm{x}} \mathrm{O}_{\mathrm{y}}\right)$ catalyst. The mechanism can be given as:

$$
\begin{aligned}
& \mathrm{Hg}_{(\mathrm{g})}+\text { surface } \rightarrow \mathrm{Hg}_{(\mathrm{ad})} \\
& \mathrm{Hg}_{(\mathrm{ad})}+\mathrm{M}_{\mathrm{x}} \mathrm{O}_{\mathrm{y}} \rightarrow \mathrm{HgO}_{(\mathrm{ad})}+\mathrm{M}_{\mathrm{x}} \mathrm{O}_{\mathrm{y}-1}
\end{aligned}
$$

During the desorption stage, the physically adsorbed mercury on the surface $\mathrm{Hg}_{\text {(ad) }}$ is released, however, the chemically adsorbed mercury $\left(\mathrm{HgO}_{(\mathrm{ad})}\right)$ remains on the sorbent surface.

NanoActive CuO sorbent: An unusual shape of the breakthrough curve was obtained when mercury was exposed to $0.2 \mathrm{gm}$ of NanoActive $\mathrm{CuO}$ sorbent at $423 \mathrm{~K}$ (see Figure 5). It can be seen that the outlet mercury concentration reached a steady value of approx. $92 \mu \mathrm{g} / \mathrm{m}^{3}$ at the end of 30 min exposure to mercury, suggesting that a complete breakthrough could never be obtained. To investigate this further, the experiment was repeated under identical conditions. A similar behavior was observed even for the repeat experiment. It is speculated that the NanoActive $\mathrm{CuO}$ sorbent has some catalytic activity that results in oxidation of a certain fraction of incoming elemental mercury. This oxidized mercury is captured by the same sorbent. Since the sorbent remains catalytically active for the duration of the experiment, mercury breakthrough is not observed. To reduce the experimental time so that a complete breakthrough could be observed, an experiment was carried out at $423 \mathrm{~K}$ with only 0.05 gm of the sorbent mixed with $1.95 \mathrm{gm}$ of inert alumina. The sorbent achieved near saturation during the $4 \mathrm{~h}$ exposure to Hg.

\section{Mercury Sorption on Presulfided Sorbents}

Presulfided NanoActive $\mathrm{CuO}$ and $\mathrm{MnO}_{2}$ sorbents were evaluated for $\mathrm{Hg}$ capture in $\mathrm{N}_{2}$ stream at 423 and $533 \mathrm{~K}$ following the procedure given earlier. Presulfided NanoActive $\mathrm{MnO}_{2}$ was not effective at either of the temperatures, whereas, presulfided NanoActive CuO was effective only at $423 \mathrm{~K}$. During the 5-h exposure to mercury, the presulfided NanoActive CuO captured nearly $370 \mu \mathrm{g} \mathrm{Hg} / \mathrm{g}$ sorbent, which corresponded to $71 \%$ of total exposed mercury. Comparison with the Hg-capacity of NanoActive CuO given in Table 1 indicates that sulfided $\mathrm{CuO}$ has higher capacity and efficiency for Hg capture. The increased capacity of the sulfided sorbent is due to the formation of $\mathrm{CuS}$ during presulfidation, which has increased affinity towards $\mathrm{Hg}$.

\section{Conclusion}

Preliminary evaluation of nanocrystalline metal oxide and sulfide sorbents was carried out in $\mathrm{N}_{2}$ stream to screen effective mercury sorbents for further evaluation in simulated fuel gas. Of the eight sorbents evaluated in this work, NanoActive $\mathrm{Cr}_{2} \mathrm{O}_{3}$ was the most effective at 423 and 533 K. NanoActive $\mathrm{MnO}_{2}$ and $\mathrm{CuO}$ sorbents also showed promise in capturing $\mathrm{Hg}$ from $\mathrm{N}_{2}$ stream. Mechanistic studies suggested that Hg was captured on the sorbent surface by a combination of physical and chemical sorption mechanisms. Sulfidation of NanoActive CuO sorbent increased its Hg-sorption capacity at $423 \mathrm{~K}$, however, the sulfided $\mathrm{CuO}$ was not effective at $533 \mathrm{~K}$.

\section{4. $\quad$ Reference}

1. Granite E.J., H.W. Pennline, and R.A. Hargis, Novel sorbents for mercury removal from flue gas, Ind. Eng. Chem. Res., 39(4), 1020-1029, 2000. 